\title{
Forskning på glia og epilepsi
}

To oversiktsartikler i dette nummer av Tidsskriftet handler om epilepsi. I artikkelen Hvordan virker antiepileptika? av Karl O. Nakken og medarbeidere kommer det frem at dagens epilepsimedisiner i hovedsak virker på ionekanaler og reseptorer i nevronene (1). Siden en tredel av pasientene ikke oppnår tilfredsstillende anfallskontroll ved monoterapi, er det naturlig å spørre om gliacellene kan være alternative angrepspunkter for behandling. Kjell Heuser og medarbeidere oppsummerer forskning som viser at glia, spesielt de stjerneformede astrocyttene, har betydning ved epilepsi (2). Hvorfor har de fleste hjerneforskere neglisjert gliacellene når det faktisk er flere gliaceller enn nevroner i hjernen?

Svaret kan være at man lenge manglet teknologi til å fange opp gliacellenes aktivitet. Glia har nemlig ikke nevronenes evne til å sende elektriske impulser. Helt siden Hodgkin og Huxley oppdaget aksjonspotensialet for 75 år siden, har klassisk elektrofysiologi vist at glia er tause når nevronene fyrer. Først med fluorescensmikroskopene i 1990-årene kom erkjennelsen av at astrocytter kan kommunisere. Aktivitet i synapsene gir nemlig økt $\mathrm{Ca}^{2+}$-konsentrasjon i astrocyttene. Slike $\mathrm{Ca}^{2+}$-signaler kan spre seg fra astrocytt til astrocytt og dessuten indusere frigjøring av glutamat og andre signalmolekyler (kalt «gliotransmittere») som virker tilbake på preog postsynaptisk nevron. Begrepet «tripartite synapse» oppsto, med henvisning til astrocytten som synapsens tredje element. Oppfatningen av astrocyttenes funksjon endret seg brått. Astrocyttene var ikke bare «vaktmesterceller», de var også aktivt involvert i sansing, læring og atferd (3).

De siste 20 årene har stadig flere forsket på samspillet mellom nevroner og glia, og det har vært store teknologiske fremskritt. Mens man tidligere brukte konfokalmikroskop på cellekulturer og hjerneskiver, gir tofotonmikroskop forskerne i dag mulighet til å studere hjernecellers aktivitet $\mathrm{i}$ levende forsøksdyr (4). Faktisk kan vi se begivenheter på synapsenivå med millisekunds tidsoppløsning. Det lages stadig flere fluorescerende indikatorer - et nytt univers ligger åpent for utforskning.

Avansert avbildningsteknologi alene er ikke tilstrekkelig for å avdekke gliacellenes betydning ved epilepsi og andre hjernesykdommer. Bildeopptak i intakt hjernevev bør kombineres med dyremodeller for sykdom samt verktøy som tillater presis manipulasjon av definerte celler. Optogenetikk er en lovende metode der lyssensitive proteiner uttrykkes i målceller og funksjonen kontrolleres med lys av bestemt bølgelengde (5). Metoden ble kåret til Method of the Year 2010 av tidsskriftet Nature Methods og er blitt brukt til å initiere og stoppe epileptiske anfall (6). Knapt noen har anvendt optogenetikk på glia, så dette er et felt med mange muligheter. De komplekse interaksjonene mellom nevroner og glia bør også studeres med matematisk modellering.

Oppdagelsen av gliacellenes kommunikasjon og teknologiske nyvinninger vil gi en mer sammensatt forståelse av epilepsi. Dyreforsøk har allerede vist at signalmolekyler fra astrocytter kan utløse epileptisk aktivitet (7). Vi vet også at epilepsi kan oppstå når astrocyttene ikke ivaretar vaktmesteroppgavene. Epilepsi ses nemlig ved mutasjon i genet til ionekanalen som astrocyttene bruker til å fjerne kalium fra synapsespalten $(8,9)$. Ved tinninglappsepilepsi med hippokampal sklerose forsvinner astrocyttenes vann- og kaliumkanaler fra membrandomener der de normalt er anriket (endeføtter rundt blodkar). Dyremodeller viser at tapet av polarisering inntrer før epilepsien er manifest og forstyrrer vann- og kaliumbalansen (10). Vannkanaler i astrocyttene regulerer også drenasjen av avfallsstoffer fra hjernen (11). Astrocyttene fungerer altså som rengjøringsmaskiner og hindrer opphopning av stoffer som kan skade nevronene. Denne «hjernevaskingen» er mest aktiv under søvn (12) astrocyttene har sitt eget natteliv!

Vi har på kort tid lært mye om glia og epilepsi, men det er fortsatt mange ubesvarte spørsmål. Vi mangler kunnskap om hva som initierer og regulerer epileptogenesen. I mange tilfeller vet vi heller ikke om forandringer i glia er skadelige eller beskyttende. Det er derfor overraskende at man i den store amerikanske forskningssatsningen The BRAIN Initiative, som tidligere er omtalt i Tidsskriftet (13), unnlot å omtale glia. Dette utløste kommentarartikkelen Map the other brain i tidsskriftet Nature (14). Forfatteren hevder at kunnskapsnivået om glia ligger hundre år etter vår viten om nevronene. Støtte til grunnforskning på glia og videre teknologiutvikling vil utvilsomt bedre forståelsen av nevron-glia-interaksjonen og bidra til å identifisere nye angrepspunkter for behandling av mange hjernesykdommer, inkludert epilepsi.

\section{Erlend A. Nagelhus}

e.a.nagelhus@medisin.uio.no

Erlend A. Nagelhus (f. 1966) er professor i fysiologi med spesialkompetanse på gliaceller. Han er leder av en forskningsgruppe ved Norsk senter for molekylærmedisin og Institutt for medisinske basalfag, Universitetet i Oslo, og har en bistilling som forsker ved Nevrologisk avdeling, Oslo universitetssykehus.

Forfatter har fylt ut ICMJE-skjemaet og oppgir ingen interessekonflikter.

\section{Litteratur}

1. Nakken KO, Heuser K, Alfstad K et al. Hvordan virker antiepileptika? Tidsskr Nor Legeforen 2014; 134: 42-6.

2. Heuser K, Szokol K, Taubøll E. Gliacellenes rolle ved epilepsi. Tidsskr Nor Legeforen 2014; 134: 37-41.

3. Volterra A, Meldolesi J. Astrocytes, from brain glue to communication elements: the revolution continues. Nat Rev Neurosci 2005; 6: 626-40.

4. Kerr JN, Denk W. Imaging in vivo: watching the brain in action. Nat Rev Neurosci 2008; 9: 195-205.

5. Tye KM, Deisseroth K. Optogenetic investigation of neural circuits underlying brain disease in animal models. Nat Rev Neurosci 2012; 13: 251-66.

6. Bentley JN, Chestek C, Stacey WC et al. Optogenetics in epilepsy. Neurosurg Focus 2013; 34: E4

7. Tian GF, Azmi H, Takano T et al. An astrocytic basis of epilepsy. Nat Med 2005; 11: $973-81$

8. Haj-Yasein NN, Jensen V, Vindedal GF et al. Evidence that compromised K+ spatial buffering contributes to the epileptogenic effect of mutations in the human Kir4.1 gene (KCNJ10). Glia 2011; 59: 1635-42.

9. Bockenhauer D, Feather S, Stanescu HC et al. Epilepsy, ataxia, sensorineural deafness, tubulopathy, and KCNJ10 mutations. N Engl J Med 2009; 360: deafness,

10. Nagelhus EA, Ottersen OP. Physiological roles of aquaporin-4 in brain. Physiol Rev 2013; 93: 1543-62

11. Iliff JJ, Wang M, Liao Y et al. A paravascular pathway facilitates CSF flow through the brain parenchyma and the clearance of interstitial solutes, including amyloid beta. Sci Transl Med 2012; 4: 147ra111.

12. Xie L, Kang H, Xu Q et al. Sleep drives metabolite clearance from the adult brain. Science 2013; 342: 373-7.

13. Brean A. Hjerne til å skjønne. Tidsskr Nor Legeforen 2013; 133: 1281.

14. Fields RD. Neuroscience: map the other brain. Nature 2013; 501: 25-7. 